\title{
Wเdya duta
}

JURNAL ILMIAH ILMU AGAMA DAN ILMU SOSIAL BUDAYA

\section{Perayaan Nyepi Umat Hindu Bali Bertindak Lokal dan Berpikir Universal}

W. Sayang Yupardhi

Universitas Udayana

Abstract

Hindu can't be seprated from ritual including its holy day. In general, the Holy Day was celebrated by most of Hindu people in Bali since 426 AD and continues from one generation to the next. The objective of the Nyepi was to balance bhuana agung and bhuana alit that in human being implemented as power,vois and mind in a certain time needs to be recharged to bring back their power as what they were. In related to Nyepi, Melasti ritual is one of rituals held generaly 3 days before the Nyepi is celebrated where symbols of Gods and Godes of Dalem, Puseh, Desa Tamles are carry to the closet sea by foot or by car or bus to furefiying. Furthermore, a day before the Nyepi called pengerupukan where ofering (caru) was offered to evels to make them calm.

During the celebration of the Nyepi, Bali fill very quite for 24 hours. It can be understood that during the 24 hours there was no air pulutions due to all of physical activities stop.for 24 hours. This is really a genius action. Where ever, all over the world, one look for it may not find the Nyepi like that, so it is very prestisious in universal live i.e. macro and micro balance. There is no cresh among sesame or other religions.

At the end of the Nyepi, excactly aday after Nyepi called Ngembak Geni, the Hindu people are not hear yet their voice who act visiting each other as brother and sister to implement results of the Nyepi reflextion in order to start a new live. Actually that time is very good to make relationship between Hindu people and other people eith difference religion or other nations (take and give) as an implementation of a Hindu principle that we are all brother and sister.

Keywords

Nyepi, catur berata penyepian, ogoh-ogoh, local genius, universal

\section{PENDAHULUAN}

Agama Hindu tidak bisa lepas dari ritual/upacara dan perayaan tahun baru (Caka) seperti agama-agama lainnya di Indonesia. Dari segi upacara, Donder (2012: 108) mengatakan bahwa umat
Hindu memang secara kasat mata terlihat sangat tekun melaksanakan upacara walau sekecil apa pun secara rutin dan turun-temurun dari nenek moyang terdahulu sampai sekarang. Hal 
ini secara tidak langsung mereka telah meyadari hidup ini adalah sebuah yadnya. Yadnya yang dilakukan dengan tulus sesuai kemampuan adalah inti dari sebuah persembahan. Para orang suci mengajarkan bahwa untuk menjadi orang bijak, maka semua perbuatan (termasuk ber-yadnya) harus merupakan persembahan kepada Tuhan (Ida Hyang Widhi).

Dalam kaitannya dengan menyambut tahun baru (Çaka) bagi umat Hindu di Bali umumnya merayakannya secara bersama dan berlanjut secara tradisi, Nyepi, dari generasi ke generasi selalu didahului dengan upacara (mecaru/taur kesanga).Walaupun beberapa desa tua di Bali misalnya Ababi, Bugbug, Tenganan, dan sebagainya mereka tidak melakukan nyepi bersama, tetapi tetap melakukan nyepi juga yang disebut penyepian desa yang dilakukan setelah ngesange atau paruman desa secara bervariasi (Bali Post 30 Maret 2014: 1). Nyepi ini tidak pernah berhenti sepanjang sejarah, karena sudah merupakan teradisi dan diyakini membawa berkah keselamatan dan kesejahteraan bhuana agung dan bhuana alit.

Tujuan Nyepi adalah untuk keseimbangan bhuana agung dan bhuana alit. Keseimbangan ini adalah sebuah titik pertemuan antara sifat-sifat positif dan negatif (baik dan buruk) manusia - terimplementasi sebagai bayu, sabda, idep (Wibawa, 2007: 45). Ibarat sebuah baterai yang memiliki massa pakai; kalau massa pakainya sedah habis maka perlu di charge kembali. Demikian pula bhuana agung dan bhuana alit ini, bhuana agung perlu diistirahatkan sejenak dan bhuana alit di charge kembali dengan melaksanakan catur berata penyepian sembari koreksi diri masing-masing. Secara universal hanya dalam keseimbangan sajalah manusia dapat merasakan kesejahteraan lahirbatin, dimana ada kesejahteraan di sana ada kedamaian, di mana ada kedamaian di sana Tuhan dapat dirasakan kehadiran-Nya.

Manfaat yang diperoleh oleh masyarakat khususnya umat Hindu Bali dalam Hari Raya Nyepi ini adalah sebagai berikut ini.

1) Dapat mengembalikan kekuatan bhuana agung dan bhuana alit sesuai dengan sifat-sifat alaminya masingmasing sehingga dengan lembaran baru ini dapat hidup lebih baik dari sebelumnya untuk persiapan yang lebih matang pencapaian tujuan utama hidup ini yakni mokshartam jagadhita ya chaiti dharma dengan konsep tabula rasa (menuangkan ideide cemerlang dalam lembaran baru tersebut yang bermanfaat bagi masyarakat banyak dan siap diimplementasikan).

2) Anak-anak muda dapat berinovasi, berkreasi dalam karya seni ogoh-ogoh walau memerlukan relatif banyak biaya untuk sebuah ogoh-ogoh. Ogohogoh yang dibuat setiap tahun tidak sama bentuknya sesuai kesepakanatan anak-anak muda di banjar bersangkutan (evolusi ogohogoh).

Dalam pelaksanaan berata penyepian masyarakat umumnya masih berpegang kuat pada upacaranya dan belum menyentuh tattwa (filsafat)-nya (menurut pendapat bebagai kaum terpelajar), sehingga falsapah Hindu yang menyebutkan bahwa kita semua adalah bersaudara, menyama beraya intern dan ekstern, saling menghormati satu sama lain, dan sebagainya belum dapat diimplementasi sesuai harapan 
dalam Hari Raya Nyepi (Tahun Baru Çaka) karena mereka itu belum paham akan arti, makna, dan fungsi Nyepi sesungguhnya, sehingga perlu diberi pemahaman sesuai kemampuan mereka.

\section{PEMBAHASAN}

Melasti adalah salah satu ritual terkait dengan Nyepi, umumnya dilaksanakan tiga hari sebelum Nyepi dengan mengusung pretima Pura Dalem, Puseh, dan Desa berjalan kaki (tradisi) ke segara (laut) terdekat untuk disucikan. Mereka dengan berpakaian adat putihputih berangkat pada pagi ataupun siang hari (sesuai pesuaran kulkul)) dan kembali sore hari itu juga ke tempat masing-masing.

Anak-anak, remaja, dewasa, orang tua semua kelihatan antusias dalam melaksanakan melasti ini, hal ini terpancar dari wajah-wajah mereka tetap segar walau berjalan kaki cukup jauh (relatif) dari desa masing-masing sampai ke laut yang dituju. Sejak hari itu terasa di desa ada keantusiasan dan berbagai aktivitas untuk menyambut hari Raya Nyepi. Tindakan mereka dalam persiapan melaksanakan Nyepi seperti ini, karena sudah dilakukan secara turuntemurun oleh leluhur mereka (warisan nenek moyang/lokal genius) bersifat lokal dan pikiran universal masih sangat relavan sampai saat ini walau di tempat atau desa-desa kabupaten lain melakukannya setelah Hari Raya Nyepi. Mereka tetap menghormatinya, karena prinsip rwabineda tetapi substansinya sama yakni keseimbangan dan keharmonisan bhuana agung dan bhuana alit.

Sehari sebelum Hari Raya Nyepi (pengerupukan) dilakukan pecaruan (nyomia bhuta kala). Krama (masyarakat
Hindu) baik laki maupun perempuan sibuk mempersiapkan sarana dan prasarana caru penyepian; ada yang ke pasar membeli alat-alat caru, ada yang mumbuat dan memasang sanggah cucuk di depan bagian kiri atau kanan angkulangkul rumah masing-masing (sesuai dengan tempat yang tersedia) untuk pelaksanaan caru di sore harinya. Jadi, benar-benar kelihatan masyarakat (Hindu) sibuk mempersiapkan segala hal yang diperlukan untuk menyambut Hari Raya Nyepi tersebut. Selesai mecaru, malam itu juga mulai sekitar jam 7 ogohogoh diarak keliling desa setempat disertai dengan gong balaganjur. Untuk pecaruan ini di masing-masing lebuh dan sanggah/merajan masing-masing anggota banjar diberikan surat edaran oleh Kelian Banjar yang diantarkan oleh prajurunya untuk pelaksanaan pecaruan tersebut, dan tirta (air suci)-nya pun semua nunas di banjar. Karena pelaksanaan pecaruan ini sama dari tahun ke tahun, kiranya tidak ada masalah berarti yang dihadapi oleh krama banjar umumnya. Semuanya berjalan lancar-lancar saja. Dari perspektif agama Hindu pelaksanaan Nyepi ini sudah sesuai dengan sastra yakni ada upacara, tattwa, dan susila (Wiana, 2013: 8) sehingga tidak ada kesimpangsiuran dan kesalahpahaman (Puja, 1975: 5).

Dulu, selelum tahun 1980-an, ogoh-ogoh ini tidak ada, masyarakat Hindu pada malam pengerupukan hanya membawa ketongan bambu atau alat lainnya yang dapat mengeluarkan bunyibunyian, dan sundih/prakpak (bahasa Bali) ke liling desa. Sedangkan ogoh-ogoh yang merupakan kreasi anak-anak muda juga ditampilkan pada pengerupuka tersebut.. Tampaknya mereka yang adalah mahluk sosial itu dan juga mahluk 
rohani hidup di dunia terus berubah. Manusia ingin mengubah dunia dan dunia itupun ikut mengubahnya. Seperti itulah keadaan manusia selalu hidup dalam perubahan (Putra, 2014: 7). Kalau dilihat dari segi sastra agama Hindu, tampaknya tidak ada buku suci yang mengunakan sarana ogoh-ogoh untuk sebuah upacara, sehingga ogoh-ogoh (dalam wujud buta kala berbagai posisi) dapat dikatakan hanya sebuah ekspresi untuk menyemarakkan dan memeriahkan suatu upacara tanpa bermuatan politis apapun. Dengan kemajuan IPTEKS sekarang ini, anak-anak muda terus terpacu juga untuk mengembangkan kreasinya dalam karya seni ogoh-ogoh lokal maupun kontemporer universal yang juga ikut mendorong perkembangan pariwisata di Bali ini.

Nyepi ini sesungguhnya sudah lama sekali dikenal di Bali. Sayang sekali masih ada yang belum tahu pasti kapan Nyepi itu mulai dikenal dan dirayakan. Ada yang mengatakan bahwa Nyepi sudah dilaksanakan di Bali sejak abad 1 masehi dan yang lainnya mengatakan sejak dahulu kala tanpa menyebut tahun/abad. Dari hasil diskusi panjang dalam proses pempelajaran di IHDN Denpasar dapat diketahui bahwa Nyepi sudah dilaksanakan di Bali pada tahun 426 masehi. Pertanyaan selanjutnya tentang mengapa Nyepi dilakukan pada Tilem (hari gelap) sasih ke sanga pada orang-orang disekitar tempat tinggal penulis mereka juga banyak yang tidak tahu jawabannya. Namun demikian, mereka sudah melaksanakan suatu upacara penyepian yang baik, walau secara filosofis mereka masih kurang pemahamannya.

Secara umum, pelaksanaan Hari Raya Nyepi dari tahun ke tahun tahun tidak ada yang keluar dari peraturan beryadnya setempat. Pada Hari Raya Nyepi umat Hindu di Bali selama 12 jam penuh tidak melalukan penyalaan api, tidak bepergian ke luar rumah, tidak melakukan aktifitas fisik dimana dan kapanpun mulai jam 6 pagi dari hari itu sampai jam 6 pagi keesokan harinya. Selama itu para pemuka masyarakat Hindu mengharapkan umat Hindu melaksanakan introspeksi diri masingmasing, meditasi, maupun ber-japam (menyebut nama-nama suci Tuhan berulang-ulang) dalam hati di rumah masing-masing sehingga Bali ini terasa senyap selama 24 jam tersebut. Dari sini dapat diambil hikmahnya bahwa selama 24 jam tersebut tidak ada polusi udara yang disebabkan oleh gas-gas polutan seperti $\mathrm{CO}_{2}, \mathrm{CO}, \mathrm{CH}_{4}$, dan sebagainya yang dikeluarkan oleh mesin-mesin motor, mobil, kapal laut, kapal udara, pabrik, asap rokok, dan sebagainya melalui asapnya masing-masing, karena semua kegiatan fisik dihentikan total selama 24 jam. Ini benar-benar sebuah tindakan lokal (lokal genius) yang dimanapun dicari di dunia ini tidak ada hari Nyepi seperti itu sehingga sangat prestisius dalam tatanan hidup universal dalam arti keseimbangan mikro dan makro kosmos. Sebagian besar hal ini sudah berjalan sepatutnya di Bali, dan dihormati juga oleh saudara-saudari yang non Hindu, tidak ada gesekangesekan berarti, di antara sesama mungkin para krama desa adat (terutama yang muda-muda) mulai menyadari betapa indahnya perbedaan dalam persatuan (unity in diversity).

Sembahyang atau solat yang dilakukan oleh umat lalam di berbagai Msjid-pun di Bali tidak terdengar alunannya. Mereka menghormati juga saudaranya dari Hindu yang sedang 
melaksanakan berata penyepian. Toleransi mereka cukup baik dengan mengusung semboyan "dimana mereka berada di sana langit dijunjung". Mudahmudahan hal ini bisa berlanjut dan tidak hanya bersifat sementara saja. Bangsa yang beradab, maju, makmur dan terhormat adalah bangsa yang dapat menghormati bengsa-bangsa lainnya di dunia ini tanpa memandang negara itu negara-negara super pawer, negara maju, negara ketiga, negara sedang berkembang atau negara terkebelakang. Di sini tidak boleh ada unsur diskriminasi antara satu negara, bangsa, status sosial, politik, ekonomi, maupun budaya. Keberpihakan pada salah satu unsur tersebut di atas ini tidak mencerminkan sifat keuniversalan. Di Bali khususnya pada umat Hindu sifat keuniversalan ini terimplementasi dalam lokal genius lainnya yaitu segalak seguluk sabayantaka terutama dalam pelaksanaan yadnya (baik-buruk dipikul bersama) baik di banjar, subak, maupun sekehesekehe tradisional lainnya yang masih eksis sampai sekarang.

\section{KESIMPULAN}

Walaupun pemikiran beberapa umat Hindu di Bali bersifat universal dalam melaksanakan yadnya, tetapi masih ada kekurangannya. Misalnya, sehari setelah Nyepi yang disebut Ngembak Gni, belum terdengar gaungnya umat Hindu yang melakukan anjangsana (kunjung-mengunjungi) ke saudara-saudaranya yang lain sebagai implementasi hasil perenungan selama Nyepi dalam rangka memulai lembaran baru dalam hidup ini. Sebenarnya waktu tersebut juga sangat baik untuk menjalin persahabatan dengan saudara-saudara kita dari lain agama maupun suku (menyama beraya) sebagai implementasi dari sebuah prinsip ajaran Hindu yakni bahwa kita semua adalah bersaudara. Tidak ada istilah terlambat, kalau mau melaksanakannya, sesunggunya dapat dilakukan kapan saja dan di mana saja. Kalau tidak memulainya sekarang, kapan memulainya? Hidup ini sangat singkat, kita tidak tahu apa yang akan terjadi sebentar lagi atau besok. Oleh karena itu, apa yang bisa dikerjakan sekarang untuk kebaikan bersama kerjakan sekarang juga, jangan menunggu hari esok. Di sini diperlukan kesabaran dan ketabahan tingkat tinggi mulai dari pemimpin desa (lokal) yang menjadi panutan. Sekecil apa pun usaha (sadhana) yang dilakukan untuk perubahan menuju kebaikan bersama melalui pemikiran-pemikiran universal, pastilah bermanfaat untuk masa depan. Tidak ada usaha yang sia-sia selama kita tetap berpegang teguh pada prinsip yang bersifat universal antara lain diversity in unity yang tercermin dalam lambang Negara Republik Indonesia yakni bhineka tunggal ika (Yupardhi, 2010: 95-96) yang dapat diimplementasi dalam hari Ngembak Gni selain hari-hari raya Hindu lainnya. Hal ini kiranya sangat baik dilakukan untuk menambah khasanah ke-Hindu-an sebagai salah satu identitas jati diri umat Hindu.

\section{DAFTAR PUSTAKA}

Bali Post. 2014. Sejumlah Daerah Steril Ogoh-ogoh. Bali Post No. 211, Tahun ke 66, Minggu Umanis 24 Maret. Denpasar.

Donder, I Ketut dan I Ketut Wisarja. 2012. Teologi Sosial. Surabaya: Paramita. ISBN 978-602-204-1900 .

Puja, Gede. 1975. Pengantar Agama Hindu III WEDA. Jakarta: Mayasari. 
Putra, Ngakan Putu. 2014. Kamu Adalah Tuhan. Cetakan Pertama. Jakarta: Madua Hindu. ISBN 978-602-75112-4.

Wiana, I K. 2013. Agni Hotra Upacara Malajahin Weda (dalam Bali Post, Minggu Umanis, 3 Nop. 2013).Denpasar.

Wibawa, Made Aripta. 2007. Kedahsyatan Agni Hotra Yajna Suci yang Terlupakan., Jl. Ploto No 2 Denpasar, Bali 80113: PT Empat Warna Komunikasi.

Yupardhi, W.S. 2010. Langkah-langkah Emas Untuk Hidup Lebih Baik. Cetakan Pertama.Surabaya: Paramita. ISBN 978-979-722-921-

4. 